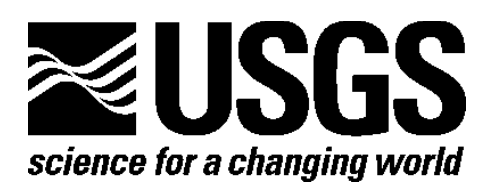

\title{
Spatial Databases of Geological, Geophysical, and Mineral Resource Data Relevant to Sandstone-Hosted Copper Deposits in Central Kazakhstan
}

By Boris Syusyura, Stephen E. Box, and John C. Wallis

Open-File Report 2010-1124

U.S. Department of the Interior

U.S. Geological Survey 


\section{U.S. Department of the Interior \\ KEN SALAZAR, Secretary}

\section{U.S. Geological Survey \\ Marcia K. McNutt, Director}

U.S. Geological Survey, Reston, Virginia 2010

For product and ordering information:

World Wide Web: http://www.usgs.gov/pubprod

Telephone: 1-888-ASK-USGS

For more information on the USGS-the Federal source for science about the Earth,

its natural and living resources, natural hazards, and the environment:

World Wide Web: http://www.usgs.gov

Telephone: 1-888-ASK-USGS

Suggested citation:

Syusyura, Boris, Box, Stephen E., and Wallis, John C., 2010, Spatial Databases of Geological, Geophysical, and Mineral Resource Data Relevant to Sandstone-Hosted Copper Deposits in Central Kazakhstan: U.S. Geological Survey Open-File Report 2010-1124, 4 p. and databases [http://pubs.usgs.gov/of/2010/1124/].

Any use of trade, product, or firm names is for descriptive purposes only and does not imply endorsement by the U.S. Government.

Although this report is in the public domain, permission must be secured from the individual copyright owners to reproduce any copyrighted material contained within this report. 


\section{Contents}

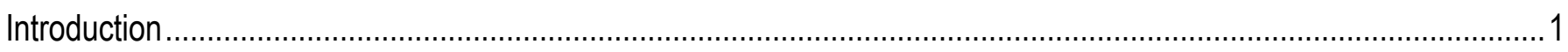

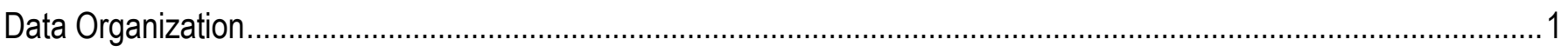

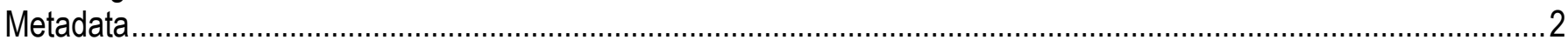

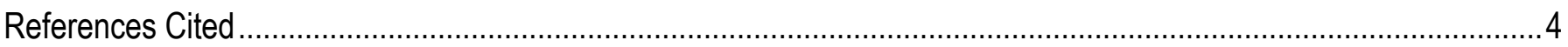

\section{Table}

Table 1. Nested folder structure for digital files in this report; each of the deepest folders contains two more folders whose name begins with that deepest folder name followed by "_GIS" which holds the georeferenced files, or with "_IMAGE" for ungeoreferenced map image files. Refer to Appendix 1 for a description of each. ..3 


\title{
Spatial Databases of Geological, Geophysical, and Mineral Resource Data Relevant to Sandstone-Hosted Copper Deposits in Central Kazakhstan
}

\author{
By Boris Syusyura, Stephen E. Box, and John C. Wallis
}

\section{Introduction}

Central Kazakhstan is host to one of the world's giant sandstone-hosted copper deposits, the Dzhezkazgan deposit, and several similar, smaller deposits (Gablina, 1981; Susura and others, 1986; Cox and others, 2003; Hitzman and others, 2005). The United States Geological Survey (USGS) is assessing the potential for other, undiscovered deposits of this type in the surrounding region of central Kazakhstan. As part of this effort, Syusyura compiled and partially translated an array of mostly unpublished geologic, geophysical, and mineral resource data for this region in digital format from the archives of the former Union of Soviet Socialists Republics (of which Kazakhstan was one of the member republics until its dissolution in 1991), as well as from later archives of the Republic of Kazakhstan or of the Kazakhstan consulting firm Mining Economic Consulting (MEC). These digital data are primarily map-based displays of information that were transmitted either in ESRI ArcGIS, georeferenced format, or non-georeferenced map image files. Box and Wallis reviewed all the data, translated Cyrillic text where necessary, inspected the maps for consistency, georeferenced the unprojected map images, and reorganized the data into the filename and folder structure of this publication.

\section{Data Organization}

The data are organized into four folders on a geographical basis:

\section{1-KAZAKHSTAN_REGIONAL}

2-TENIZ-BASIN

3-CHU-SARYSU-ENTIRE

4-CHU-SARYSU-SUBAREAS

Within each of these folders, the data are further divided into separate folders by geologic data type (such as geology, geophysics, structure contour, and so on) and/or by geographic subarea (table 1). The digital data are separated at the lowest folder level into two additional folders by data format: (1) georeferenced map data in a folder whose name ends in "_GIS" and (2) nongeoreferenced map images and other illustrative images in a subfolder whose name ends in "_IMAGES". Within the folder containing the two data format folders are two files that can be used to launch programs to view the georeferenced map files: a file in ".MXD" format that opens the maps in ESRI ArcGIS (version 9.1) and a file in ".PMF" format that allows a dynamic view of the same maps (read only) in ESRI ArcReader"T, 
which is available for download at no cost from

http://www.esri.com/software/arcgis/arcreader/download.html . An image file with the same name (.JPG format) of the layout version of the .MXD or .PMF file is presented in each "IMAGE" folder, in some cases with other nongeoreferenced images. A complete listing of all of the files included in this publication with brief descriptions of their contents is given in Appendix 1. Information about the coordinate system, data type, scale, and path for the georeferenced datasets is given in Appendix 2. The path to each of the image files is given in Appendix 3. The file name, coordinate system, scale, and path for each layout is given in Appendix 4.

File-naming conventions are as follows:

- The capitalized letters preceding the first underscore (“") indicate the area (and thus the folder) in which the map data occurs: $\mathrm{KZ}_{-}$for regional Kazakhstan data which reside in the 1-KAZAKHSTAN_REGIONAL folder, TZ_ for Teniz Basin data which reside in the 2-TENIZ-BASIN folder, CS _ for Chu-Sarysu Basin data that cover the entire basin and resides in the 3-CHU-SARYSU-ENTIRE folder, and CS-XX_for data from a subarea within the Chu-Sarysu Basin which resides in the 4-CHU-SARYSU-SUBAREAS folder.

- The "XX " " for the subareas within the Chu-Sarysu Basin comes from the first two letters of the subarea name. "-NCS" indicates data sets covering much of the northern half of the Chu-Sarysu Basin, while "-WCS_" indicates data sets covering much of the western part of the northern Chu-Sarysu Basin.

- Following the first underscore ("_") are lower-case whole or shortened words (or directional abbreviations like "ne-" for northeast) that briefly describe the data represented in the file.

\section{Metadata}

The datasets have been compiled in digital format primarily from unpublished paper versions of geological, geophysical, and mineral resource data for this region from the archives of the former Union of Soviet Socialists Republics (of which Kazakhstan was one of the member republics until its dissolution in 1991), as well as from later paper or digital archives of the Republic of Kazakhstan or of the Kazakhstan consulting firm Mining Economic Consulting (MEC). These digital data are primarily map-based displays of information that were georeferenced in ESRI ArcGIS either by the MEC group in Kazakhstan or by the USGS group in Spokane, Wash. Some of the ancillary digital data are given as non-georeferenced image files.

Appendix 2 lists the data as known for each of the datasets, and includes the dataset name, the ESRI layout (.MXD or .PMF) in which the dataset is shown, the coordinate system, the data type, which group performed the rectification (if ending in "-3", the dataset is a scanned image that was rectified to fit the layout projection by using a 3 rd order transformation in ArcGIS), the nominal scale of the dataset, and the pathname for the location of the dataset. Only limited information is available about the creation and source of these "legacy" files. A single FGDC standard metadata was prepared for the entire dataset. The datasets are essentially provided "as-is" in an effort to allow interested researchers access to this otherwise inaccessible data. 
Table 1. Nested folder structure for digital files in this report. Each of the deepest folders contains two more folders whose name begins with that deepest folder name followed by "_GIS", which holds the georeferenced files, or with "_IMAGE" for nongeoreferenced map image files. Refer to Appendix 1 for a description of each.

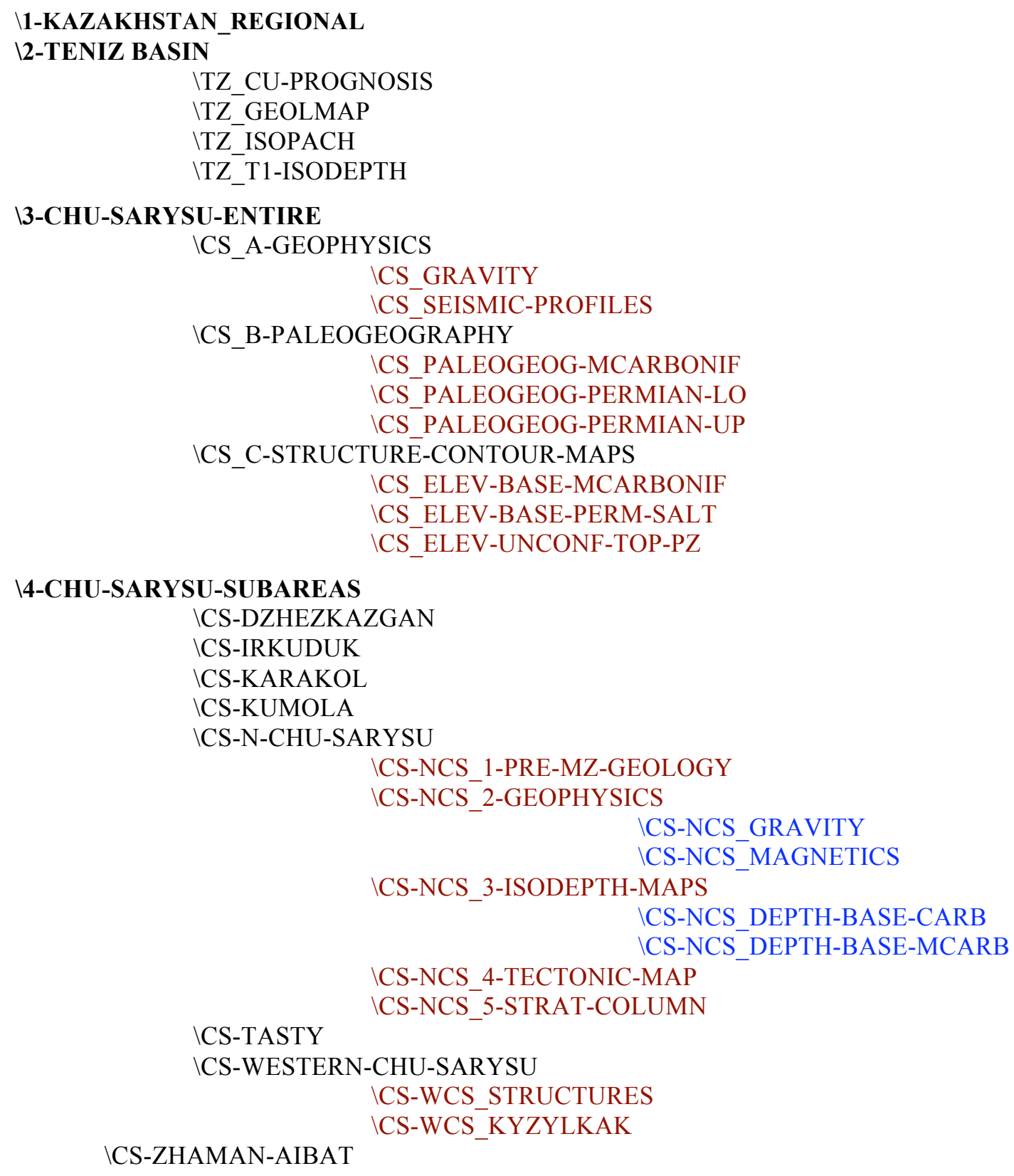




\section{References Cited}

Cox, D.P., Lindsey, D.A., Singer, D.A., and Diggles, M.F., 2003, Sediment-hosted copper deposits of the world-Deposit models and database: U.S. Geological Survey Open-File Report 03-107, 50 p. [http://pubs.usgs.gov/of/2003/of03-107/].

Gablina, I.F., 1981, New data on formation conditions of the Dzhezkazgan copper deposit, International Geology Review, v. 23, no. 11, p. 1303-1311.

Hitzman, Murray, Kirkham, Rodney, Broughton, David, Thorson, Jon, and Selley, David, 2005, The sediment-hosted stratiform copper ore system: Economic Geology $100^{\text {th }}$ Anniversary Volume, p. 609-642.

Susura, B.B., Glybovsky, V.O., and Kislitsin, A.V., 1986, Red-colored terrigenous sediments - Specific copper-forming systems, in Friedrich, G.H., ed., Geology and metallogeny of copper deposits: Berlin, Springer-Verlag Publishing, p. 504-512. 